УДК $616.711-007.5-053.6$

\title{
ПОНЯТТЯ І ВИДИ ПОРУШЕННЯ ПОСТАВИ У ПІДЛІТКІВ
}

\author{
Н. В. Тимошенко
}

\author{
Конотопське медичне училище
}

У статті проаналізовано літературні джерела 3 питань етіології та патогенезу порушень постави у підлітків. Правильне положення тіла в просторі дозволяє людині легко утримувати рівновагу і рівномірно розподіляти навантаження на верхні та нижні кінцівки, на м'язи спини. Як правило, сколіоз починає розвиватися у людини ще в ранньому дитинстві, коли вона починає ходити в школу, довгий час сидить за партою в неправильному положенні, сутулиться, а потім та ж історія повторюється і вдома за уроками.

\section{CONCEPT AND TYPES OF POSTURAL DISORDERS IN ADOLESCENTS}

\author{
N. V. Tymoshenko
}

\section{Konotop Medical School}

The article contains a literature review, describing the etiology and pathogenesis of posture disorders in adolescents. Proper body position in space allows a person to easily keep balance and evenly distribute the load on the upper and lower limbs, the muscles of the back. Usually, scoliosis begins to develop in humans in early childhood, when children start visiting school, keep incorrect positions sitting at a desk and become bent.

Вступ. Постава - це звичне положення тіла людини, манера триматися стоячи і сидячи. Постава не передається у спадок, її формують в родині, дитячому закладі, в побуті й на роботі. Неправильна постава, ще в дитинстві, зумовлює розвиток різних захворювань, що впливає на моральний і психічний стан людини. Діти з порушеною поставою під час ходьби опускають голову, сутуляться. Хода у них тяжка, що супроводжується поганою координацією рук і ніг. Виникненню неправильної постави сприяють такі шкідливі звички, як сидіти із підігнутою ногою, закинутою за спинку стільця рукою, стояти з відставленою в сторону ногою. При цьому таз перебуває в нахиленому положенні, а хребет викривлений.

Негативний вплив на поставу має сидіння за занадто низьким або високим столом. У дітей, які сидять за високим столом, розвивається грудний сколіоз - одне плече піднімається, а хребет у грудному відділі викривляється. Низький стіл змушує дитину нахилити тулуб, внаслідок чого збільшується вигин хребта в грудному відділі $[1,7]$.

Постава у дітей і підлітків має ряд вікових особливостей. Так, до початку статевого дозрівання, особливо виражений поперековий лордоз. Зміна постави у дітей в процесі росту і розвитку пов'язана зі зміщен-

(c) Н. В. Тимошенко, 2017 ням загального центру маси тіла, що у дівчаток відбувається у віці 11-12 років, а у хлопчиків - 12-13 років. Саме в цей період необхідно бути особливо уважним до дитини, стежити за її поставою.

Люди з правильною поставою рухаються вільно, красиво, їхні внутрішні органи перебувають в правильному положенні та працюють в оптимальному режимі. Кожна людина набуває індивідуальну поставу, яка формується протягом усього життя під впливом ряду факторів. Найважливішим є розвиток мускулатури, так званого м'язового корсету $[2,3,5,9]$.

Основна частина. Постава залежить від ступеня вираженості вигинів хребта і фізичної підготовленості людини.

Основні типи постави:

1. Нормальна постава: форми тіла людини з правильною поставою пропорційні, голова розташована прямо, плечі розправлені, злегка відведені назад, груди опуклі, живіт втягнутий. Нормальна постава характеризується такими ознаками:

- симетричним розташуванням таза;

- симетричністю обох лопаток;

- однаковою формою трикутників, утворених бічною поверхнею тулуба і внутрішньою поверхнею опущених рук;

- прямим розташуванням голови; 
- симетричністю плечового пояса;

- однаковою довжиною рук і ніг.

2. Плоска спина: це тип постави, при якому природні вигини хребта згладжені, лопатки мають крилоподібну форму. Грудна клітка недостатньо опукла, зміщена вперед, нижня частина живота також видається вперед. Плоска спина, як правило, є наслідком слабкого розвитку скелетної мускулатури. Функціональна неспроможність м'язів випрямляє хребет, при плоскій спині сколіоз прогресує дуже швидко. Людина з поставою такого типу тримається напружено, її рухи незграбні.

3. Сутулість: це найбільш відоме порушення постави, при якому спостерігається загальне збільшення грудного кіфозу. У таких людей запалі груди, виступаючі лопатки, плечі опущені вперед, голова нахилена, живіт випнутий. Діти з такою поставою не можуть тривалий час перебувати у випрямленому положенні, оскільки швидко втомлюються. Існують вправи для корекції неправильної постави, спрямовані на розтягнення м'язів на ввігнутій стороні хребта і скорочення м'язів на вигнутій.

4. Кругла спина: положення тіла при круглій спині характеризується такими ознаками:

- кривизна хребта збільшена у верхній його частині;

- голова зазвичай нахилена вперед;

- грудна клітка сплощена;

- плечі опущені вперед;

- лопатки мають крилоподібну форму, спина округла;

- живіт випнутий або звисає;

- сідниці сплощені;

- коліна напівзігнуті.

- м'язи тулуба в такому положенні ослаблені, тому прийняти правильну поставу можна лише на короткий час.

5. Кругло-увігнута спина: постава такого типу характеризується наступними ознаками:

- надмірно посилені фізіологічні вигини хребта шийний, грудний, поперековий, крижовий в передньо-задньому напрямку;

- таз надмірно нахилений вперед;

- сідниці різко випнуті назад;

- живіт сильно виступає вперед;

- голова, шия і плечі нахилені вперед;

- грудна клітка сплощена, талія вкорочена.

Спостерігається недорозвинення м'язів черевного преса, що зумовлює опущення внутрішніх органів $[2,4,6-9]$.

Ступені порушення постави:
- перший ступінь - неправильна постави тіла зникає в положенні стоячи. В даному випадку порушення постави легко виправити фізичними вправами, що формують м'язовий корсет;

- другий ступінь - спостерігаються стійкі порушення, що не зникають при змінах положення тіла. Для їх усунення необхідно систематично виконувати спеціальні коригувальні фізичні вправи в поєднанні з вольовою корекцією постави в м'язовій системі. Для їх виправлення потрібне тривале і систематичне лікування з обов'язковими заняттями коригувальною гімнастикою.

Причини, що сприяють порушенню постави, з досліджень І. С. Дронова, можна поділити на три групи. До першої групи належать фактори загального ендогенного характеру (обмінно-гормональні дисфункції, різні захворювання внутрішніх органів), послаблюючих нервово-м'язовий апарат. Другу групу складають чинники екзогенного характеру - несприятливі умови навколишнього середовища, ультрафіолетова недостатність, зниження рухового режиму, недостатнє перебування на свіжому повітрі і т. д. До третьої групи належить сукупна дія ендо- і екзогенних чинників [2, 4, 6-9].

Причинних факторів порушення постави дуже багато. У різні періоди життя дитини переважне значення можуть мати то одні, то інші фактори, то їх комплекси. Однак всі автори вказують на те, що більшість порушень постави у дітей шкільного віку має набутий функціональний характер і пов'язані вони з нераціонально організованим процесом виховання.

При відсутності будь-яких патологічних процесів в організмі, але при дефекті постави насамперед потрібно встановити причину її зміни, починаючи 3 визначення контрактур великих суглобів.

Контрактура плечового суглоба найчастіше виникає через ретракції (укорочення) великих грудних м'язів, коли втрачається здатність до підняття рук вгору без того, щоб не з'явився виражений поперековий лордоз. Правильніше контрактуру можна встановити таким чином: посадивши дитину на табурет, щільно притискають її спину до стіни, після чого піднімають обидві руки дитини догори. У цей момент виявляють поперековий лордоз, вимірюють кут між піднятими руками і стіною, що дає можливість визначити контрактуру плечових суглобів у градусах $[3,6,9]$.

При тривалому положенні грудного відділу в патологічному стані виникає фіксований грудний кіфоз, який визначається підняттям хворого з горизонтального положення в сидяче. Рука лікаря, підкладена під 
грудний відділ, не відчуває звичайної рухливості між остистими відростками, а ротаційні рухи в грудному відділі відсутні.

Контрактура кульшових суглобів, причинами якої можуть бути слабкість великих сідничних м'язів, гіперфункція згиначів стегна або вкорочення клубово-стегнової (бертінієвої) зв'язки, перевіряють симптомом Томаса. Для цього у хворого в положенні лежачи на спині, притискають зігнуту ногу до живота; при цьому на кут контрактури піднімається інша нога. Фіксований поперековий лордоз перевіряється після зникнення лордозу при піднятті двох ніг одночасно і прижати їх до живота. Причиною контрактури сіднично-колінних м'язів є вкорочення двоголового, напівсухожильного, напівперепончастого м'язів стегна [9].

Характерні симптоми даної патології: дитина не може дістати кінчиками пальців рук до підлоги або сидячи на підлозі з випрямленими в колінних суглобах ногами, не може дістати кінчики пальців ніг руками, а сидячи на стільці з випрямленими колінними суглобами, відхиляє тулуб назад. Іноді в нижньогрудному відділі утворюється помітний кіфоз.

Висновки. Зазначені порушення, що призводять до патологічної постави, більшою чи меншою мірою

\section{СПИСОК ЛІТЕРАТУРИ}

1. Абальмасова Е. А. Лечение врожденных и диспластических деформаций опорно-двигательного аппарата у детей и подростков / Е. А. Абальмасова, Е. В. Лузина. Ташкент : Медицина, 1979. - 121 с.

2. Алдер М. В. Режим и диспансерное наблюдение детей и подростка со сколиотической болезнью / М. В. Алдер, Г. А. Росляков. - Рига : МЗ Латв. СССР, 1989. - 20 с.

3. Алемасов Р. Ю. Организация консервативного лечения сколиоза у детей / Р. Ю. Алемасов, Ф. Умарходжаев // Проблемные вопросы травматологии и ортопедии. Ташкент, 1992. - С. 4-16.

4. Погосян М. М. Массаж : монография / М. М. Погосян. - 2-е изд. дополн. и перераб. - М. : Советский спорт, 2009. - 784 c. позначаються на становищі, а іноді й на функції внутрішніх органів грудної та черевної порожнин. Причини, які можуть призвести до сколіозу, багаточисленні. Поява сколіозу пов'язана з недостатньою чутливістю рецепторів, що визначає вертикальне положення хребта або послаблення м'язів, що утримують це положення, з обмеженням рухливості у суглобах, акселерацією сучасних дітей. Причинами сколіозу можуть бути також незручний одяг, захворювання внутрішніх органів, зниження зору, слуху, недостатнє освітлення робочого місця, невідповідність зросту дитини розміру меблів та ін. Дискогенні сколіози формуються на ґрунті дисплазії хребта, при яких ядро міжхребцевого диска первинно зміщується, внаслідок чого виникають всі наступні ланки сколіотичної хвороби. Гравітаційні сколіози виникають внаслідок порушення симетрії тіла дитини щодо хребта: при кривошиї, грубих однобічних рубцях, перекосі таза, вкороченні м'язів на одній стороні. Міотичні сколіози виникають при функціональній неспроможності м'язів тулуба, внаслідок ураження нервової системи при церебральних інфекціях, міопатії, поліомієліті.

5. Полеся Г. В. Лечебное плавание при нарушении осанки и сколиозе у детей / Г. В. Полеся, Г. Г. Петренко. К. : Здоров'я, 1980. - 113 с.

6. Попов С. Н. Физическая реабилитация: учебник ; под общей ред. С. Н. Попова. - 3-е изд. - Ростов-на-Дону : «Феникс», 2005. - 608 с.

7. Геврик $Є$. О. Гігієна праці на виробництві: навч. посіб. для студентів вищих навч. закладів / Є. О. Геврик, Н. П. Пешко. - К. : Ельга Ніка Центр, 2004. - 276 с.

8. Гогіташвілі Г. Г. Системи управління охороною праці : навч. посіб. / Г. Г. Гогіташвілі. - К. : ІСДО, 1993. - 252 с.

9. Мухін В. М. Фізична реабілітація / В. М. Мухін. К. : Олімпійська література, 2005. - 472 с. 